\title{
EFFECT OF SIMULATED FLOODING AND NITROGEN APPLICATION ON NITROGEN UPTAKE OF RICE
}

\author{
J.A. Adjetey ${ }^{*}$ and Q.S. Mulbah ${ }^{2}$ \\ ${ }^{1}$ Department of Crop Science and Production, Botswana University of Agriculture and Natural Resources, \\ Private Bag 0027, Gaborone, Botswana \\ ${ }^{2}$ Discipline of Crop Science, University of KwaZulu-Natal, Scottsville 3209, Pietermaritzburg, South Africa \\ Corresponding author: jaadjetey56@gmail.com
}

Keywords: Flooding, grain yield, nitrogen use efficiency, rice

\begin{abstract}
In lowland rice production systems, flooding patterns vary during the cropping period and this poses a serious challenge to productivity due to the effect of flooding on the availability and uptake of nitrogen. The aim of this study was to examine the influence of various flooding patterns on nitrogen use in rice grown under simulated wetland conditions. Rice was grown in a greenhouse at 0,110 and $220 \mathrm{~kg} \mathrm{~N} \mathrm{ha}^{-1}$ under well watered control conditions, continuous flooding, early flooding at tillering, and late flooding post-tillering. The results showed that continuous and early flooding increased tiller production and grain yield compared to late flooding or non-flooded conditions. Although the highest grain yields under the different flooding patterns were obtained with $220 \mathrm{~kg} \mathrm{~N}$ ha-1, the combination of $110 \mathrm{~kg} \mathrm{~N}^{-1}$ and early flooding also significantly increased tiller productivity, nitrogen recovery, and agronomic nitrogen use efficiency (NUE). There is the need to regulate the supply of nitrogen and water resources if grain yield and NUE has to be increased at minimal costs. Also, compared to well-watered conditions, rice production under flooded conditions lead to increased productivity and $\mathrm{N}$ rate must match realistic target yields. Best results are obtained when flooding occurs in the early rather than later parts of the season.
\end{abstract}

\section{Introduction}

Rice is a principal grain crop in many sub-Saharan African countries where it is a major source of carbohydrates for thousands of households. It is produced mainly for subsistence by rural farm families with very little or no modern agricultural inputs, including fertilizers. The rice farming system in sub-Saharan Africa is dominated by shifting cultivation in upland fields where about 78- $90 \%$ of the crop is produced under rain-fed conditions (Balasubramanian et al., 2007). As a result, yield is low and seldom exceeds 1.5 tha $^{-1}$. By 2006 , rice consumption had exceeded production (Nasrin et al., 2015) by at least $50 \%$, primarily as a consequence of declining output since the latter part of the 1980s (WARDA, 2007).

Although rice is not an aquatic plant, its yield can be improved with above average moisture supply (Sarwar and Khanif, 2005; Kikuta et al., 2017). Currently, sub-Saharan African farmers are shifting towards lowland rice culture characterized by periodic flooding, to achieve increased productivity with the improved water supply associated with the lowlands, and also, promote sedentary farming (Dolo, 2009). Due to the uncertain flooding patterns associated with these lowlands, there is a need to develop insights into the effect of flooding patterns on the production of the crop. Of the major fertilizer resources, nitrogen is the most intensively used in rice cropping systems. Insufficient plant nitrogen results in chlorosis, reduced photosynthesis and stunted growth, while excessive amounts encourage luxuriant growth, lodging, diseases, and delays maturity (Takebe and Yoneyama, 1989; Peng et al., 2010). Like nitrogen, elevated 
Adjetey et al.

soil moisture regimes promote the growth and development of rice crops (Juraimi et al., 2009; Kikuta et al., 2017). In most countries, rice is grown in wet or lowlands where water conditions are not easily predictable, particularly in respect of flooding times. Excessive moisture can negatively influence nitrogen use efficiency, and consequently, crop yield. This study therefore, examined the effects of different simulated flooding patterns and nitrogen application rates on the growth and yield of rice.

\section{Materials and Methods}

The study was conducted in a greenhouse with day / night temperatures of $30^{\circ} \mathrm{C} / 20^{\circ} \mathrm{C}$ at the Life Sciences Campus of the University of KwaZulu-Natal in Pietermaritzburg. The cultivar "Golden Mountain \# 1" (GM-1) was used in this study. The experiment was a factorial combination of four simulated flooding regimes and three nitrogen rates, laid out in a completely randomized block design with four replications. The water regimes which were simulations of possible field moisture situations in wetland rice cropping were: well watered control (NF), continuous flooding (CF), early flooding (EF), and late flooding (LF). Double layer of clear plastic bags of 15 microns thickness were used to line the inner portion of the $4.8 \mathrm{~L}$ pots containing the flooded treatments, to prevent leakage through the pot drainage holes. Each pot was then filled with $10 \mathrm{~kg}$ air-dried soil (28\% clay, 1.5\% organic matter, $1.5 \%$ acid saturation) and well watered. Two hills were sown per pot with three seeds per hill, spaced 17 $\mathrm{cm}$ apart at a depth of $1 \mathrm{~cm}$. Prior to sowing, seeds were soaked in tap water for $24 \mathrm{~h}$, following which they were incubated at $30^{\circ} \mathrm{C}$ for another $24 \mathrm{~h}$ in order to stimulate vigorous germination. The plants were thinned to one seedling per hill at two weeks after sowing.

Tensiometers (Irrometer Company, California) were used to monitor the soil water status in the root zones of the plants subjected to no flooding, to ensure they were always well watered and soil moisture tension in the root zone was kept below $15 \mathrm{k} \mathrm{Pa}$ throughout the experimental period. The flooding regimes were achieved by maintaining standing water at $5 \mathrm{~cm}$ from the soil surface in the $4.8 \mathrm{~L}$ pots. Commencing at 21 days after sowing (DAS), the early flooding regime lasted until 51 DAS (i.e. 30 days) when tillers had fully formed, while the continuous flooding regime lasted up to 7 days before harvest (i.e. 70 days). The late flooding commenced at 51 DAS (near booting) and lasted for 40 days i.e. until 7 days before harvest. Urea (46\% N) was applied at 0,110 , and $220 \mathrm{~kg} \mathrm{~N} \mathrm{ha}^{-1}$, in three split doses of $50 \%$ at $20 \mathrm{DAS} ; 25 \%$ at mid tillering (45 DAS) and $25 \%$ at booting (60 DAS). The amount of fertilizer was calculated on the basis soil analysis results. There was a basal application of $20 \mathrm{~kg} \mathrm{P} \mathrm{ha}{ }^{-1}$ using single super phosphate and no other fertilizers were required.

A portable plant efficiency analyzer (Hansatech, UK) was used to measure the leaf chlorophyll fluorescence at 30 DAS and at heading (65 DAS). A circular spot on the upper surface of each leaf was dark adapted for 20 minutes using dark adaptation clips, and the maximum quantum yield of photochemistry $(\mathrm{Fv} / \mathrm{Fm})$ recorded. Tiller production was monitored weekly from three weeks after sowing until heading. At heading, one plant per pot was randomly harvested for leaf area, above ground biomass, and nitrogen determination. Leaf area per plant was measured with a portable leaf area meter (LI-3000, LI-COR Biosciences) equipped with a LI$3050 \mathrm{~A}$ belt conveyor. Above ground dry matter was measured after oven-drying at $70{ }^{\circ} \mathrm{C}$ for $48 \mathrm{~h}$ to constant masses. Plant tissue nitrogen concentration was determined by the Dumas combustion method, using a Tru Spec CN - elemental analyzer (LECO Corporation). Whole dried shoot material was ground to powder using a ball mill (Spex Industries 8000). Sub samples of $0.125 \mathrm{~g}$ were weighed, sealed in tin capsules and loaded for analysis. 
Effect of Simulated Flooding and Nitrogen Application on Nitrogen Uptake of Rice

Nitrogen uptake at heading was determined as the product of the above ground dry mass and tissue nitrogen concentration. Nitrogen use efficiency (NUE) was assessed as nitrogen recovery efficiency and agronomic efficiency as:

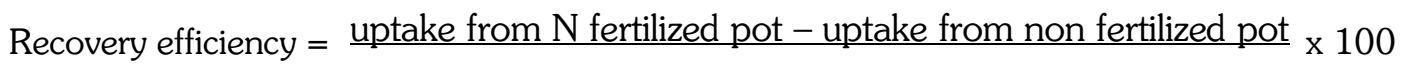
$\mathrm{N}$ applied

Agronomic efficiency $=$ grain weight in $\mathrm{N}$ fertilized pot - grain weight in non fertilized pot $\times 100$ $\mathrm{N}$ applied

Panicle number, spikelet fertility, and grain weight were measured at maturity. Unfilled spikelets were separated from filled spikelets by water flotation. Grain weight was determined at grain moisture content of $14 \%$.

The data were subjected to analysis of variance (ANOVA) using the windows statistical software package, GENSTAT version 12. The means of treatments showing significant difference were subjected to Least Significance Difference (LSD) test. Relationship between factors was further assessed by Pearson's correlation and regression analysis using the statistical software SPSS 15.0 for Windows.

\section{Results and Discussion}

\section{Tiller and panicle production}

A high number of tillers $(P<0.001)$ was produced under both continuous and early flooding compared to the well watered controls and late flooding treatments (Figure 1a).
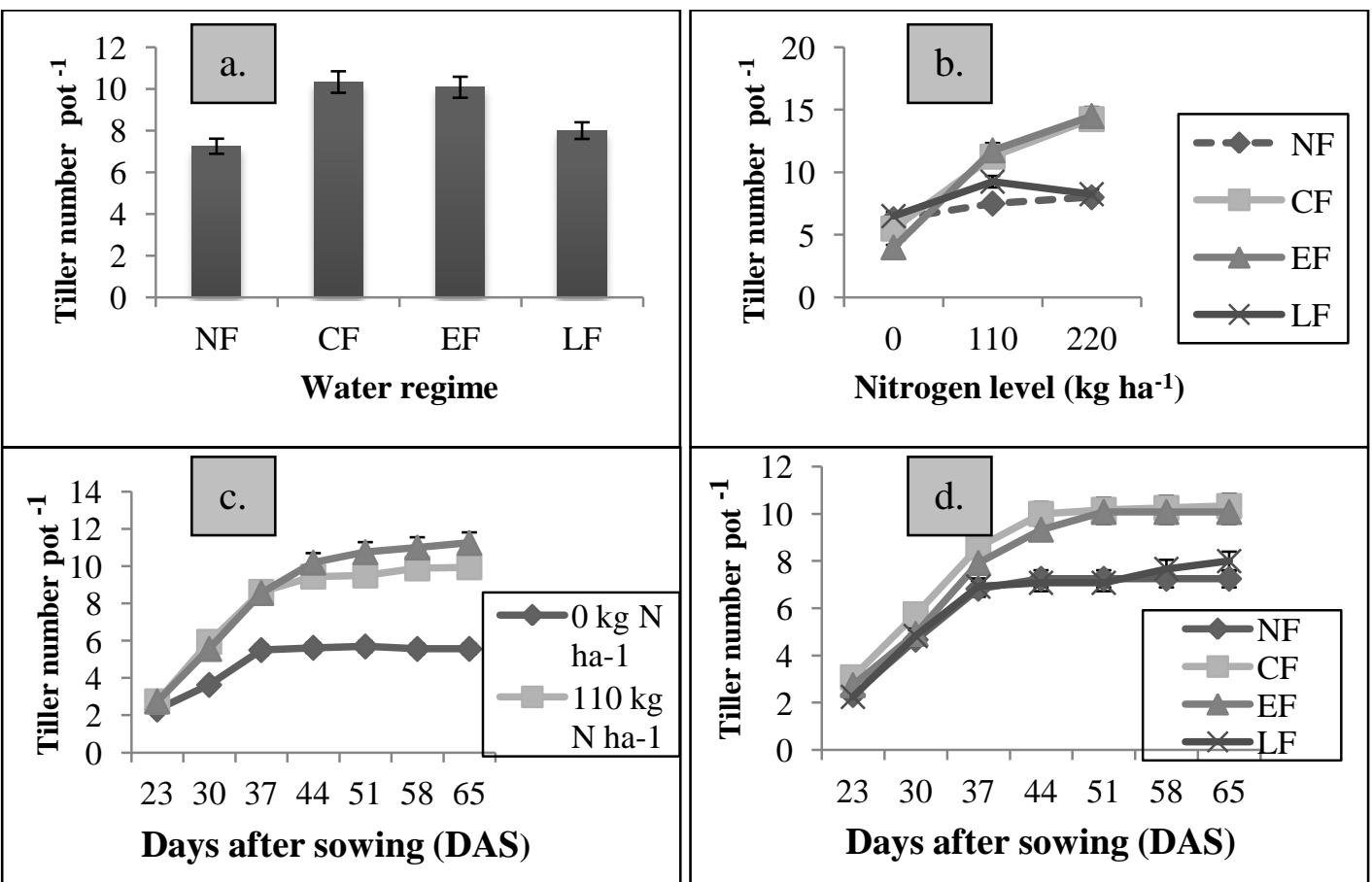
Adjetey et al.

Fig. 1. Effect of flooding regimes and nitrogen rates on tiller production in rice grown in green house conditions. Error bars show 95\% CI of means.

\section{Chlorophyll florescence}

The ratio of variable florescence to maximum florescence (Fv/Fm) neither changed with nitrogen rate, nor with water regime at both 30 DAS and at heading (65 DAS). Mean values ranged from 0.77 to 0.79 at $65 \mathrm{DAS}$, and 0.79 to 0.80 at heading (Figure $2 \mathrm{~d}$ ), indicating that the plants were relatively free from stress.

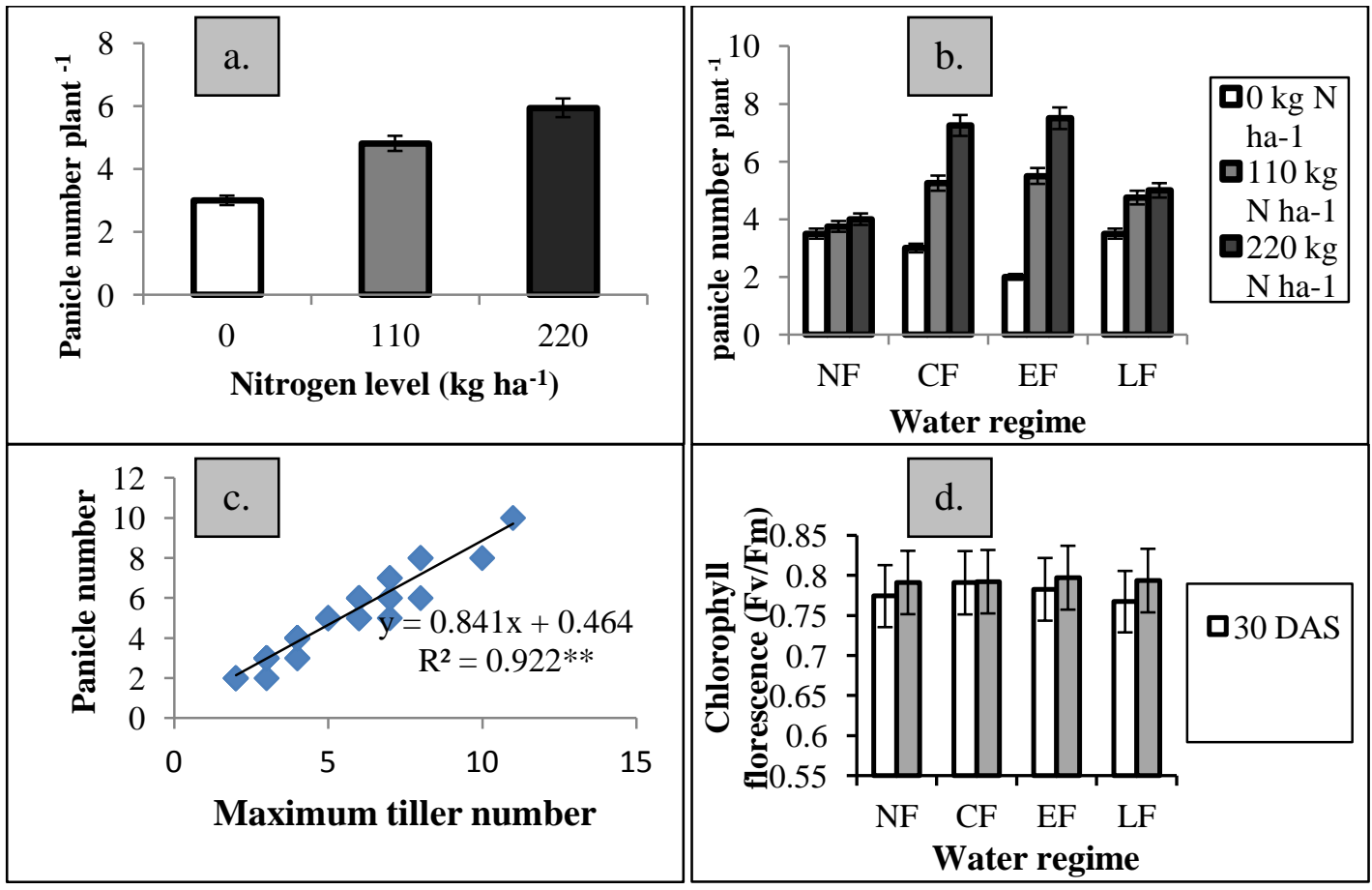

Fig. 2. Effect of flooding regimes and nitrogen rates on panicle production and chlorophyll fluorescence in rice grown in greenhouse conditions. Error bars show 95\% CI of means

\section{Leaf area, dry mass and nitrogen status}

There was a significant interaction $(P<0.001)$ between the nitrogen rates and water regimes in respect of leaf area and shoot dry mass (Figures $3 a$ and $3 b$ ). When no nitrogen was applied, these parameters were significantly higher for those grown under early flooding compared to the other water regimes. At $110 \mathrm{~kg} \mathrm{~N} \mathrm{ha}^{-1}$, water regime did not affect leaf area development, however, leaf area increased with continuous and late flooding at $220 \mathrm{~kg} \mathrm{ha}^{-1}$.

At $220 \mathrm{~kg} \mathrm{~N}$ ha-1 plants had the highest nitrogen concentration compared to those grown without nitrogen fertilizer (Figure 3c). Plants grown under non-flooded conditions also had high $(\mathrm{P}<0.01)$ concentration compared to those continuously flooded. Plant tissue nitrogen concentration increased with increasing nitrogen input under all but the late flooding water regime, in which nitrogen concentration showed little increase beyond the $110 \mathrm{~kg} \mathrm{~N} \mathrm{ha}{ }^{-1}$ rate. Plant nitrogen uptake was 4 - 5 times higher at 110 and $220 \mathrm{~kg} \mathrm{~N}^{-1}$ than for the control 
Effect of Simulated Flooding and Nitrogen Application on Nitrogen Uptake of Rice

treatment. However, uptake was only 1.3 times higher at $220 \mathrm{~kg} \mathrm{~N}^{-1}$ compared to $110 \mathrm{~kg}$ $\mathrm{N}$ ha ${ }^{-1}$ (Figure 3d). At $110 \mathrm{~kg} \mathrm{~N} \mathrm{ha-1}$, there was no significant difference in nitrogen accumulation for all the water regimes. At $220 \mathrm{~kg} \mathrm{~N} \mathrm{ha}^{-1}$, nitrogen uptake by plants in both the continuous and early flooding regimes was significantly higher than those of the other two moisture regimes.

\section{Nitrogen use efficiency}

Nitrogen recovery was higher at 110 than at $220 \mathrm{~kg} \mathrm{~N}^{-1}$ (Figure 4a). Also, recovery at both nitrogen levels was higher with continuous and early flooding compared to the non-flooded and late flooded regimes. Nitrogen recovery was less than $42 \%$ in all treatments but poorest in the late flooding treatment. The agronomic nitrogen use efficiency i.e. the ability of plants to increase yield in response to fertilizer input was higher for 110 than $220 \mathrm{~kg} \mathrm{~N} \mathrm{ha}^{-1}$ under all the moisture regimes (Figure $4 \mathrm{~b}$ ). At both nitrogen levels, agronomic nitrogen use efficiency was highest for early flooding, followed by continuous flooding.

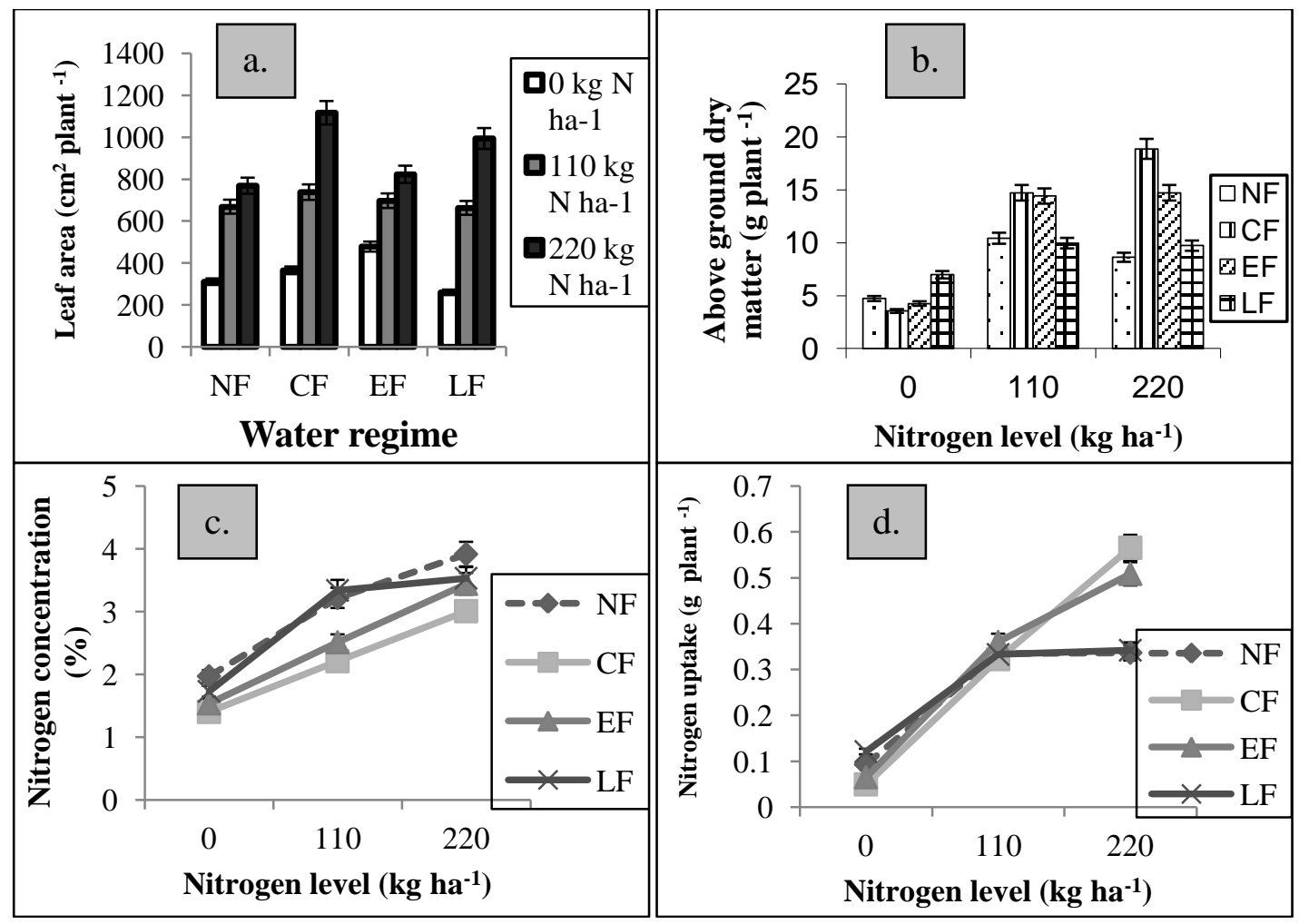

Fig. 3. Effect of flooding regimes and nitrogen rates on leaf area, dry mass, nitrogen concentration and uptake in rice grown in greenhouse conditions. Error bars show 95\% CI of means.

\section{Spikelet fertility and grain yield}

Spikelet fertility reduced only slightly $(P<0.05)$ in plants grown under continuous flooding (Figure 4c). Nitrogen rate did not affect $(P>0.05)$ spikelet fertility (Figure $4 d$ ) and overall, 
Adjetey et al.

spikelet fertility was always higher than $80 \%$ irrespective of treatments. There was nearly a twofold increase in grain yield per plant when nitrogen rate increased from 0 to $110 \mathrm{~kg} \mathrm{ha}^{-1}$; however, only a small increase was observed beyond this level (Figure 5a). Plants subjected to early flooding produced the highest grain yield $(\mathrm{P}<0.01)$ compared to those in the nonflooded and late flooding regimes (Figure $5 \mathrm{~b}$ ). Without nitrogen, yield was lower as a result of continuous and early flooding. At $110 \mathrm{~kg} \mathrm{~N} \mathrm{ha}^{-1}$, yield increased with flooding irrespective of when it occurred. However, at $220 \mathrm{~kg} \mathrm{ha}^{-1}$ yield was limited by the non-flooded and late flooding treatments.

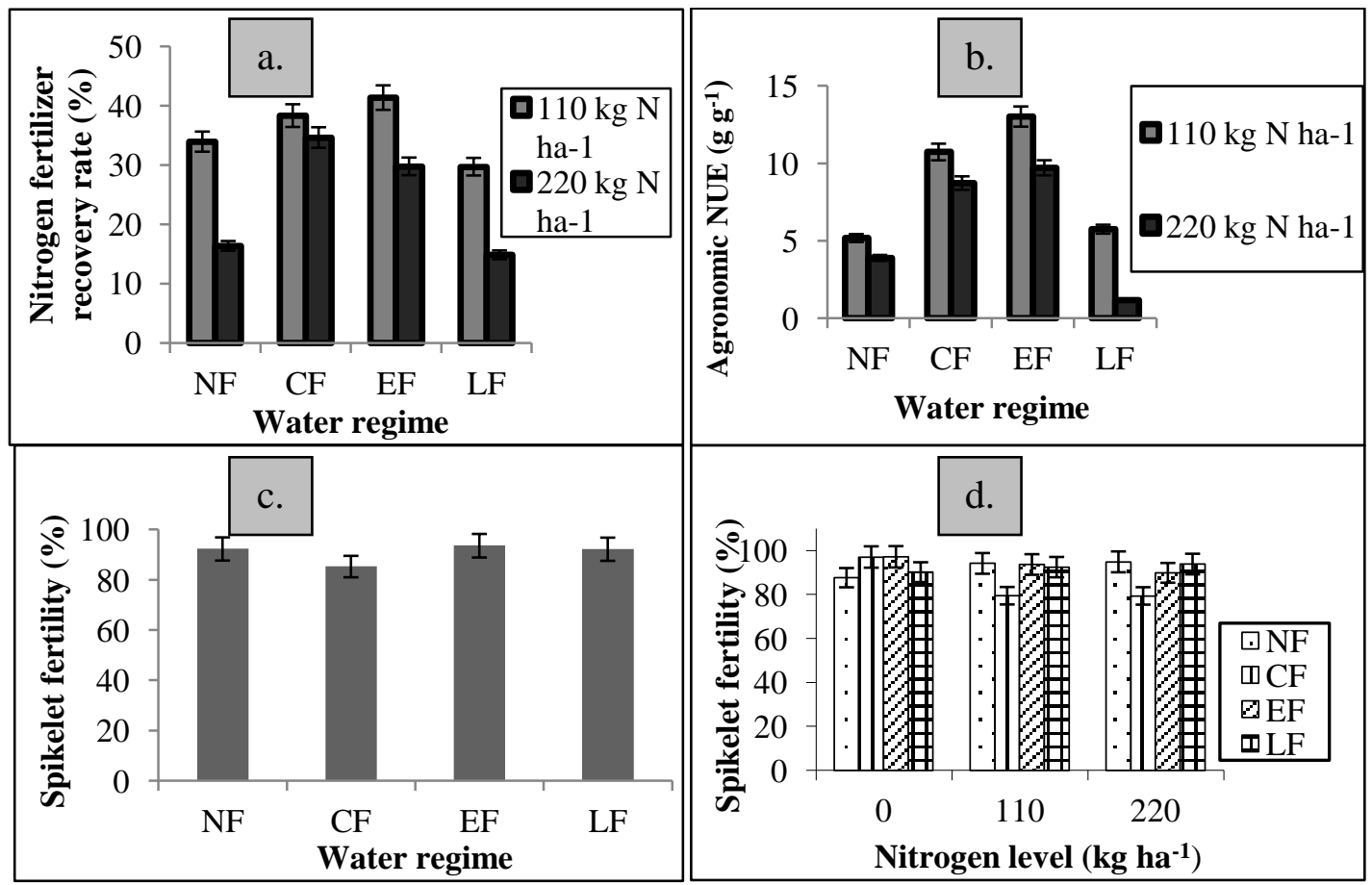

Fig. 4. Effect of flooding regimes and nitrogen rates on nitrogen recovery, agronomic use efficiency, and spikelet fertility in rice grown in greenhouse conditions. Error bars show 95\% CI of means.

\section{Relationship between tiller number, dry mass nitrogen uptake and grain yield}

There was a significant positive linear relationship $\left(\mathrm{r}^{2}=0.82, \mathrm{P}<0.001\right)$ between tiller and panicle number on one hand and grain yield on the other (Figure $5 \mathrm{c}$ ). Although panicle yield was strongly dependent on tillering $(r=0.96)$, only $77 \%$ of the variation in grain yield could be explained by the maximum number of tillers produced. Assessment of grain yield as a combined function of tillers and panicles revealed a non-significant estimate of the tiller coefficient ( $\mathrm{t}$ pr. > 0.05), suggesting that unlike tillers, panicles were the principal determinants of grain yield (Figure 5c). Grain yield was positively related ( $r=0.85$ ) to shoot biomass at heading (Figure 5d) as well as total accumulated nitrogen in the plant $(r=0.89)$ at that time (Figure 6). Grain yield increased by $0.813 \mathrm{~g}(\mathrm{t} \mathrm{pr} .<0.001)$ for every gram of increase in above ground dry matter and by $24.9 \mathrm{~g}$ for every gram of nitrogen accumulated by the time of heading. 


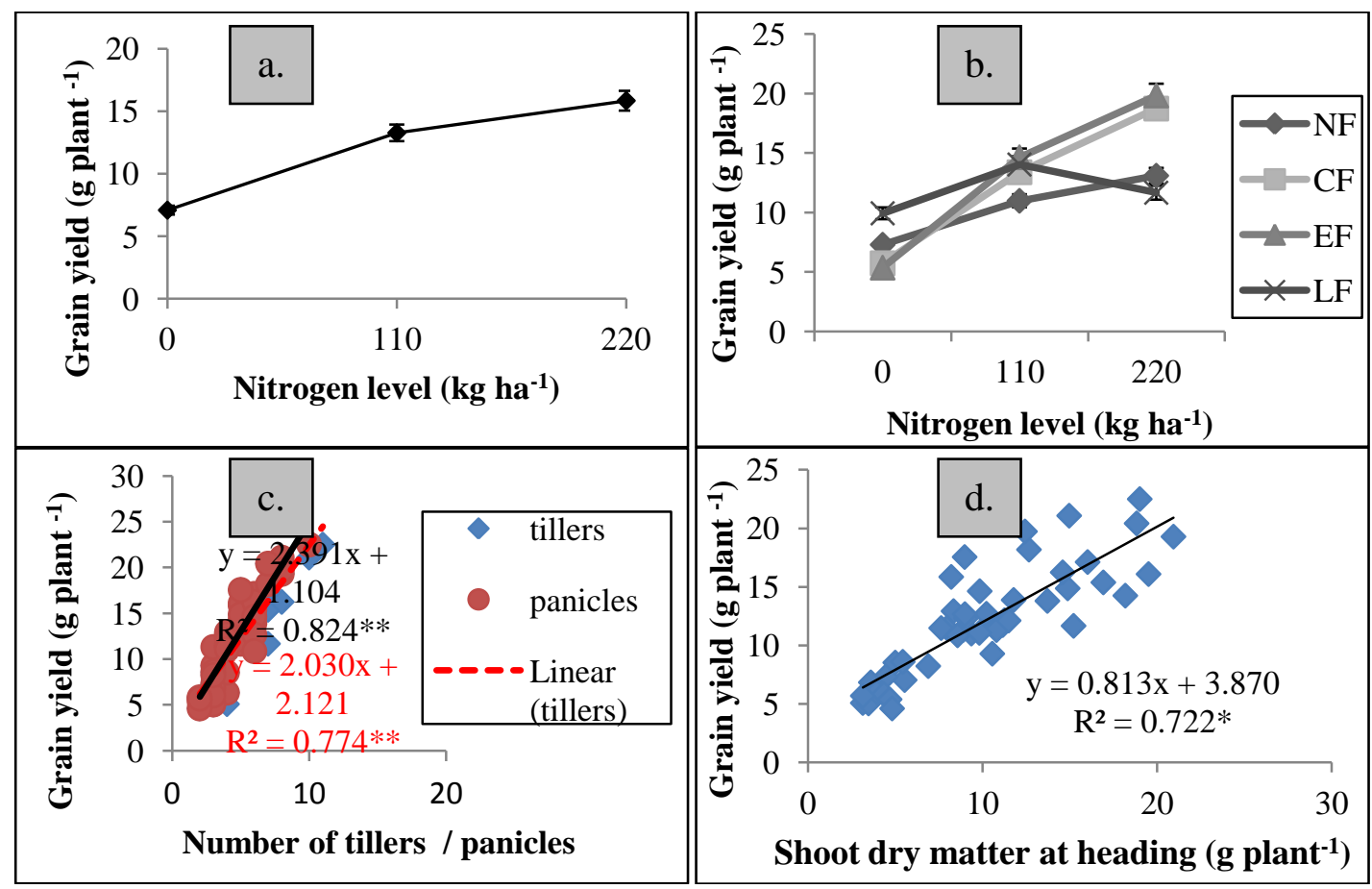

Fig. 5. Relationship between nitrogen application rate, shoot dry mass and tillers/panicle with grain yield. Data points show means for different nitrogen application rates. Error bars show 95\% CI of means.

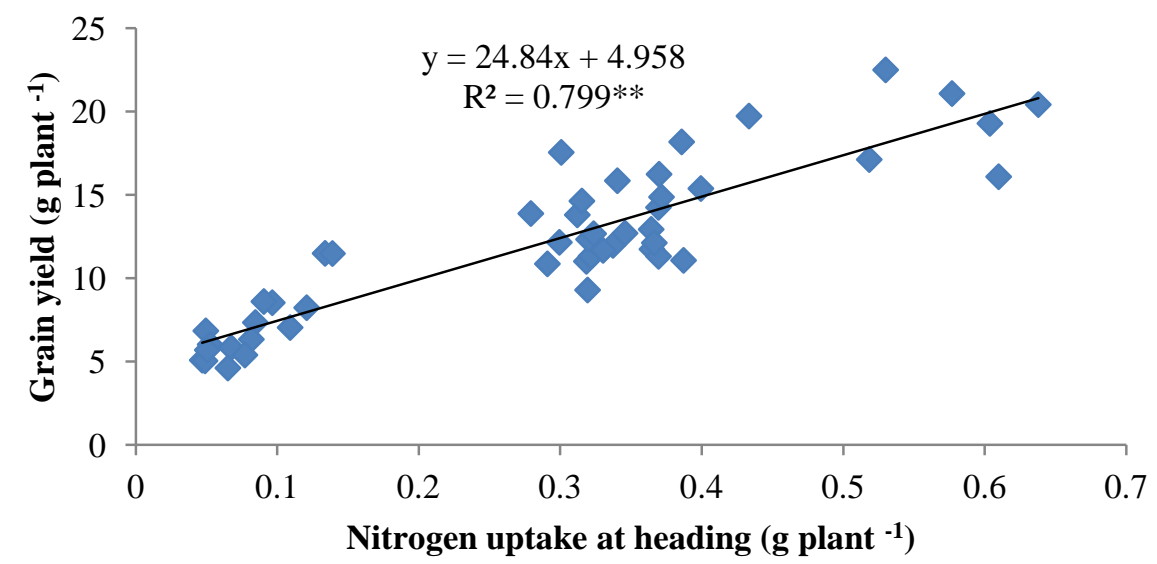

Fig. 6. Relationship between nitrogen uptake at heading and grain yield. Data points represent counts for both water regimes and nitrogen dosage $(n=48)$. 
Adjetey et al.

The overall grain yield response to the nitrogen treatments strongly correlated with the number of tillers, panicles and nitrogen uptake. However, the diminishing response between 110 and $220 \mathrm{~kg} \mathrm{ha}^{-1}$ suggests that beyond the requirements for a realistic target yield e.g. $6 \mathrm{t} \mathrm{ha}^{-1}$ at the $110 \mathrm{~kg} \mathrm{~N} \mathrm{ha-1}$ level in this study, the excessive biomass has little immediate benefit to grain yield. Such diminishing returns have been reported ( Tilman et al., 2002; Li et al., 2015). Nitrogen application rate affected spikelet fertility only to a little extent as plants grown without nitrogen fertilizer did not produce many empty spikelets but rather only a few grain-bearing tillers. Prolific tillering, coupled with inadequate nitrogen can lead to a reduction in the percentage of fertile spikelets (Mauad et al., 2003).

The fact that both $\mathrm{N}$ recovery and agronomic $\mathrm{N}$ use efficiency were higher at $110 \mathrm{~kg} \mathrm{~N}$ ha-1 than at $220 \mathrm{~kg} \mathrm{~N} \mathrm{ha}^{-1}$, raises questions about the fate of excessive nitrogen application. Low efficiency of nitrogen use at higher nitrogen rates have been attributed to losses via pathways such as $\mathrm{NO}_{2}$, $\mathrm{NO}$ and $\mathrm{N}_{2}$ emissions, and $\mathrm{NH}_{3}$ volatilization or to immobilization by soil microorganisms (Hirel et al., 2007). To ensure efficient agronomic use of nitrogen, Peng et al. (2006) have recommended the reduction of nitrogen rate to around $120 \mathrm{~kg} \mathrm{ha}^{-1}$ in high tillering rice plants, a value close to the most efficient one adopted in this study, and to the 70$90 \mathrm{~kg} \mathrm{ha}^{-1}$ reported by Shultana et al. (2015).

In the current study, both continuous and early flooding treatments increased the number of tillers and panicles, above ground biomass, leaf area and nitrogen uptake and grain yield suggesting that they are better in lowland production than late flooding or non-flooded conditions. In the current study, however, because plants subjected to continuous or early flooding produced the highest grain yield in response to nitrogen compared to the other two water regimes, we suggest that those patterns of flooding are better for yield improvement. Late flooding was the least useful of the flooded treatments as it not only led to reduced $\mathrm{N}$ uptake and $\mathrm{N}$ use efficiency but also stimulated the production of late and unproductive tillers with the potential for interfering with harvesting of mature panicles produced earlier in the season. The poor nitrogen use efficiency obtained under the late flooding and non-flooded conditions indicates that most of the applied nitrogen was wasted in those treatments.

\section{Conclusion}

Based on the findings of the study it was concluded that both continuous and early flooding led to a significant increase in nitrogen recovery, nitrogen use efficiency and grain production. All the simulated flooding conditions produced better yields than the non-flooded conditions. This suggested that irrespective of the flooding pattern, better yields were associated with lowland conditions although late flooding was the least desirable of the options. Thus flooding regimes are significant for improved yields, in lowland areas that are fed by abundant rainfall.

\section{References}

Balasubramanian, V., M. Sie, R.J. Hijmans and K. Otsuka. 2007. Increasing rice production in sub-Saharan Africa: challenges and opportunities. Adv. Agron. 94: 55-133.

Dolo, J. S. 2009. Nation-wide assessment of wetlands in large rubber concession areas. Ministry of Agriculture, Monrovia, Liberia. 
Effect of Simulated Flooding and Nitrogen Application on Nitrogen Uptake of Rice

Hirel, B., J. Le Gouis, B. Ney and A. Gallais. 2007. The challenge of improving nitrogen use efficiency in crop plants: towards a more central role for genetic variability and quantitative genetics within integrated approaches. J. Exp. Bot. 58: 2369-2387.

Juraimi, A. S., M. A. H. Saiful, M. Begum, A. R. Anuar and M. Azmi. 2009. Influence of flooding intensity and duration on rice growth and yield. Pertanika J. Trop. Agric. Sci. 32: 195-208.

Kikuta, M., D. Makihara, N. Arita, A. Miyazaki and Y. Yamamoto. 2017. Growth and yield responses of upland NERICAs to variable water managementunder field conditions. Plant Prod. Sci. 20(1): 36-46.

Li, Y., Y. Chen, C. Wu, X. Tang and X. Ji. 2015. Determination of optimum nitrogen application rate in Zhejiang Province, China, based on rice yields and ecological security. J. Integ. Agric. 14(12): 2426-2433.

Mauad, M., C. A. C. Crusciol, F. H. Grassi and J. C. Correa. 2003. Nitrogen and silicon fertilization of upland rice. Scientia Agrico. 60: 761-765.

Nasrin, S., J. B. Lodin, M. Jirstrom, B. Holmquist, A. A. Djurfeldt and G. Djurfeldt. 2015. Drivers of rice production: evidencefrom five Sub-Saharan countries. Agr. Food Sec. 4(12): 1-19.

Peng, S., R. J. Buresh, J. Huang, X. Zhong, Y. Zou, J. Yang, G. Wang, Y. Lui, R. Hu, Q. Tang, K. Cui, F. Zhang and A. Dobermann. 2010. Improving nitrogen fertilization in rice by site-specific N management. A review. Agron. Sustain. Dev. 30: 649-656.

Shultana, R., M. A. A. Mamun, M. A. K. Bhuiyan and A. J. Mridha. 2015. Response of NERICA rice to nitrogen fertilization. Bangladesh Agron. J. 18 (2): 9-14.

Sarwar, M. J. and Y. M. Khanif. 2005. Effect of different water levels on rice yield and $\mathrm{Cu}$ and Zn concentration. J. Agron. 4: 116-121.

Takebe, M. and T. Yoneyama. 1989. Measurement of leaf color scores and its implication to nitrogen nutrition of rice plants. Japan Agric. Res. Quart. 23: 86 - 93.

Tilman, D., K. G. Cassman, P. A. Matson, R. Naylor and S. Polasky. 2002. Agricultural sustainability and intensive production practices. Nature. 418: 671-677.

WARDA. 2007. Africa Rice Trends 2007 Brief. Africa Rice Center (WARDA), Cotonou, Benin. 